trate its limited resources on a comparatively few projects, it is eager to place on its agenda for consideration all the meritorious proposals, from whatever source, that come to it. We regard the library profession as a talented and vigorous ally in the promotion of reading, and look to you both as a source of suggestions and as invaluable aides in the evaluation of proposals that come before us.

\title{
Brief of the Minutes of the Meetings of the ACRL Board of Directors
}

\section{Meeting, January 29, 1952, at Chicago}

Present were officers and directors, section and committee chairmen, ACRL representatives on ALA Council, and several invited guests.

President Ellsworth opened the meeting by calling for committee reports. Mr. Swank mentioned briefly the need for information on audio-visual equipment in colleges and urged support of the questionnaire being sent out by the Committee on Audio-Visual Work to some two thousand institutions. Mr. Muller reported recent articles in College and $R e$ search Libraries covering building plans and the buildings conference to be held in Columbus in April. This conference needed the help of several consultants if it was to carry on successfully the work of the former Cooperative Committee on Library Buildings. Mr. Muller spoke briefly on the practice of recommending building consultants to institutions with building problems. $\mathrm{He}$ felt his list of consultants was getting out of date and was not sure to what extent recommendations led to actual hiring of consultants.

Mr. Swank reported as past chairman of the Committee on Constitution and By-Laws that, as things stood, his committee held an undesirable veto power over proposed legislation. The committee therefore recommended the Constitution be amended (as voted below). It was understood that once this action became final the committee would prepare legislation upon instruction of the Board of Directors.

The motion was passed unanimously that, the Committee on Constitution and By-Laws be instructed to prepare a written recommendation proposing the deletion of the phrase "upon a written recommendation of the Committee on Constitution and By-Laws appointed by the president" from Article IX and Article $X$ of the ACRL Constitution to be submitted to a vote of the members of the association.

As chairman of the Committee on Administrative Procedures $\mathrm{Mr}$. Parker reported the serious budget situation facing many college libraries, and requested instruction as to whether his group should attempt to "pressure" institutions whose library standards were hopelessly inadequate. President Ellsworth requested a recommendation from the committee on this point.

In the absence of Miss Wixie Parker, Mr. Hamlin reported that she was well started in managing the Duplicates Exchange Union of ACRL.

Miss Herrick summarized the activities of the Committee on Financing College and Research Libraries, which was now attempting to focus its influence on a few places likely to produce advertisements for the journal. Mr. Hamlin said that eight pages of advertising were expected for the April issue and described promotional material prepared in his office.

Mr. Reid summarized the final report of the Committee to Study Materials for Instruction in the Use of the Library, which is now available at the headquarters office. $\mathrm{Mr}$. Reid recommended that a promotional film should be prepared to sell the library to the students, and this was referred to the present chairman, Mr. Wyman Parker. (It is unlikely that ACRL will be able to produce a film. The committee will probably be eliminated, on joint recommendation of past 
and present chairmen, at the next board meeting unless opinion to the contrary is expressed.)

At this point President Ellsworth recognized Charles W. David, retiring executive secretary of the Association of Research Libraries, and noted Mr. David's interest in the problem of the overlapping of the two organizations.

Mr. Burke spoke on the problem of membership and invited suggestions as to what his committee members should do. He noted that membership had not increased in the past two years and invited ideas from all. $\mathrm{He}$ suggested that his committee reach every member by direct mail with a request to enlist one new member for ACRL for 1952. (At the Friday discussion it was decided that the proposed direct mail contact was unwise at this time.)

The report of the Nominating Committee (reproduced elsewhere in this issue with biographical sketches) was accepted.

Mr. Orne reported for the Committee on Preparation and Qualifications for Librarianship that they expected to assure that ACRL aims were represented in the work of the Board of Education for Librarianship. A main point was the need that education for librarianship be on the graduate level, and this was personally distressing to him.

Mr. Reichmann reported for the Publications Committee that the first two ACRL MONOGRAPHS were out and invited attendance at a subsequent program arranged by his committee.

In the absence of G. Flint Purdy, Mr. Hamlin reported that the annual statistics were mailed out in preprint form on January 9 or 10. For the first time salary information for the current academic year was included.

Treasurer Shaw commented briefly on the financial arrangement for the support of the divisions by ALA and pointed out that the first year under the new plan resulted in a two thousand dollar drop in income. He felt that membership distribution of the journal plus the less favorable financial plan spelled a serious situation for the treasury. Mr. Shaw commented on the troubles involved in a fiscal year ending in August. It was voted that, the Committee on Constitution and $\mathrm{By}$ Laws consider as a committee assignment the preparation of a written recommendation proposing the changing of the end of the ACRL fiscal year from August 31, to some date such as the end of May so that the Treasurer will be in a position to present his annual report at the annual conference. This is suggested in order that the Board of Directors may have a clear picture of finances at the time these are discussed. The Treasurer's report for the first quarter was accepted by general consent.

The Association's loss in the death of Robert W. Christ was a matter of general concern, and it was voted that Mr. Hamlin draft a formal resolution expressing to Mrs. Bessie Christ the sympathy and sense of loss of the ACRL Board of Directors in the death of her son Robert Christ. Andrew Eaton was appointed to fill the post of ACRL representative on ALA Council, left vacant by Mr. Christ's death.

It was decided that the 85 gift subscriptions of College and Research Libraries to foreign libraries would be continued indefinitely as a contribution to international good will.

The board officially approved the following statement regarding College and Research $\mathrm{Li}$ braries: "Subscription price: to members of the Association of College and Reference Libraries paying American Library Association dues of $\$ 6.00$ or more, $\$ 2.00$ per year, included in the membership dues assigned by ALA to ACRL; to members paying less than $\$ 6.00$ and to nonmembers, $\$ 4.00$ a year. Single copies \$1.25; orders of five or more @ \$1.00 each."

It was voted that, honorary ALA members who have previously been regular ACRL members be accorded all the rights and privileges of ACRL membership and that this include any publications distributed to the bulk of the membership. Similar action regarding pre-1940 life members of ALA was postponed until Friday, when the following motion was passed: That, the pre-I940 ALA life members who are ACRL members be considered on the same basis as post-1940 ALA life members who are ACRL members in connection with the membership distribution of College and Research Libraries.

Mr. Hamlin asked for and was given approval of the use of minor amounts from his travel funds for the entertainment at meals of visitors to headquarters.

Mr. Hamlin outlined a plan for a highly 
selective card bibliography of those books most useful as contributions to knowledge. This might initially include twenty or thirty thousand titles. Additions and subtractions would be made at regular intervals by scholars. Each card would include a brief annotation, and the service would be sold on a subscription basis. The cards would be useful as a basic catalog and guide to the most useful books not so much for book selection by the library as by the reader, although both purposes would be served. The plan was suggested by Mr. Pargellis of the Newberry Library. It was being considered by the Board of the American Council of Learned Societies, and should be approved by ACRL and ALA so that funds to finance the initial bibliography could be secured. It was felt that subscriptions would finance the continuation. After considerable discussion it was decided to table the proposal until the Friday meeting, at which Mr. Pargellis would be present.

The board then considered briefly several matters before Congress. It was unanimously voted that:

The ACRL Board of Directors supports H.R. 4059, the bill to protect the copyright of works in English by foreign authors.

The ACRL executive secretary be instructed to present to the Senate Committee the view of the Board favoring insertion of a provision in S.1940 to provide books for veterans in the new G.I. educational benefit bill.

The ACRL Board of Directors goes on record favoring the passage of the customs simplification bill H.R. 5505 (the bill to get the limit on informal importation of foreign books through the post office without customs declaration raised from $\$$ roo to $\$ 250$ or even $\$ 500$ ).

The board discussed but took no action on the move to use federal income from tidewater oil to support education, under certain conditions.

Mr. Ellsworth briefly discussed presidential difficulties in filling committee assignments and suggested the president-elect might want a committee to assist him in this exacting responsibility.

The budget for College and Research $\mathrm{Li}$ - braries was approved after discussion. Mr. Orne suggested the desirability of a business manager. Printing contracts and charges by Banta, the present publisher, were examined. There was much criticism of the charge for ALA general office services, which seemed exorbitant. The group reviewed unsuccessful efforts in the past to have this charge reduced. Mr. Hamlin reviewed previous Board action which authorized membership distribution subject to the findings of a special committee that the cost should not run above a $\$ 5,000$.oo initial outlay plus an annual subsidy of $\$ \mathrm{I}, 800.00$.

Mr. Hamlin described the informal meetings, begun recently, of executive secretaries at ALA Headquarters. He stated that the problem of divisional support by ALA had been discussed in detail with officers of the Public Libraries Division and suggested one of these people be invited to sit in when the ACRL Board considered this subject. The Public Libraries Division Board had, in turn, invited ACRL to be represented at its discussion, and the vice president volunteered to attend, and this exchange of views was approved. Miss Rutzen, vice president and president-elect of the Public Libraries Division, was in turn invited to sit with the ACRL Board.

President Ellsworth reviewed ACRL experience with the ALA experimental fiscal plan for the support of divisions. In presenting this a year and a half ago ALA felt that as much or more support would come to ACRL as under the old plan. 1950/51 experience showed a $\$ 1,600.00$ reduction, or a loss of about $10 \%$.

At its July meeting the ACRL Board had officially requested a simpler formula whereby every membership dollar of divisional members would be split (probably about 50/50) and the tortuous complexities of the experimental plan would be avoided. No action had been taken for or against the ACRL request. Mr. Ellsworth stated that unless ACRL took extreme action, some compromise was necessary to prevent a serious financial situation (loss of revenue for the current year was estimated at $\$ 2,725.00$ less than under the old dues and former basis of support).

Mr. Hamlin was questioned on his previously expressed hope that the experimental plan, adopted in 1950 , would be favorable to 
ACRL. He stated that he had hoped for increase in membership, but a small decline had taken place. Inflation was more of a factor under the new plan than under the old. Finally, he confessed misplaced confidence and optimism. He pointed out that ACRL was sadder and wiser from a year's experience with the formula, but should it step out at this point and go back to the old, it might be criticized as uncooperative and grasping.

Mr. Adams stated that the original proposal provided $60 \%$ of all personal dues (except the $\$ 3.00$ category) to the division of choice, and that ALA dropped this principle when the dues were raised. He pointed out that only $30 \%$ of a top personal dues payment now came to the division of choice. It was therefore suggested that ALA be petitioned to. restore the previous formula of full $60 \%$ for all personal dues except the $\$ 3.00$ category. Some analogous arrangement should be made for institutional dues.

Mr. Downs, a member of the ALA Executive Board, stated the matter had come up for discussion before them the previous evening at so late an hour that discussion was limited. The Executive Board felt that the whole dues income picture was at the moment so cloudy that no formula revision should be undertaken until June or July. If the situation then indicated considerable dues income above that of the previous year, a fair distribution would be made to the divisions. $\mathrm{Mr}$. Coney concurred in this. $\mathrm{He}$ stressed the need to accept the principle of negotiation for funds by the divisions within ALA. "There isn't any right or wrong to it. Each group always needs money. The only thing to do is to negotiate... with as even a temper as possible."

Mr. Ellsworth stressed the continual urgency for funds one feels while serving on the ALA Executive Board, "You see a dollar and allot it, and it is hardly ever allotted for divisional purposes. I think the ALA Board will follow precedent and do that, and I therefore think that all divisions should be insistent with the ALA Board that they think of this side of the problem."

The board was requested to give Mr. Ellsworth and Mr. Hamlin instructions as to attitude in a meeting with the ALA Executive Board the next day, but only expressed confi- dence in their judgment.

\section{Meeting, February I, 1952, at Chicago}

Present were officers and directors, and Messrs. Pargellis, Coney, and Tauber as guests.

Mr. Severance as president-elect expressed himself in favor of a committee to advise the incoming president on potential candidates for committee work. This group should study the work of committees and prepare panels of candidates. Discussion followed on the advantages of having committees made up of members from one section of the country. It was voted that, there be an ACRL Committee on Committees to study ACRL committees and advise the incoming president of potential candidates for committee work.

President Ellsworth spoke briefly on the responsibility of the President to get committee reports in before board meetings so that discussion would center on specific points in the reports.

At the meeting on January 29 a proposal for a system of ACRL state representatives had been discussed briefly. This called for one person in each state to represent ACRL interests in a very broad capacity, to keep in regular contact with ACRL Headquarters, to see that it was informed about local needs, talented workers, etc., to act for ACRL at state meetings, to speak for the association on all possible occasions, and in other ways to be a local "executive secretary" or arm of the national group. This discussion was continued on the basis that, if adopted, the "state representatives" would take the place of the present "state membership chairmen" and the ACRL Membership Committee would be abolished. State representatives would work on membership as well as other matters. Mr. Hamlin stressed the need of regular contact by the headquarters office with every one of these people. He stated that the plan could be tried for a year on a small scale. A motion to try the plan on an experimental basis was amended to implement the whole proposal for .1952/53, and abolish the Membership Committee in July, as follows: That, ACLR adopt a system of state representatives (Appendix VI, tentative agenda for midwinter) to have broad assignments and authority to promote the establishment of chapters, to arrange when feasible for ACRL 
programs at state and local conferences, to bring proposals for investigation and research from state groups to the national headquarters, and in general to see that ACRL is more active locally. This system of state representatives will be put into effect for the years 1952/53. The present Membership Committee will be continued until July r952.

The Committee on Interlibrary Loans was praised for its work and mildly reproved for sometimes bringing out a product which was not in finished form. Mr. Ellsworth expressed the need to bring public and special library interests to bear on the problem. The group discussed the machinery to represent the interests of librarians outside the college and reference field, and the original purposes of the Committee on Interlibrary Loans, which were being exceeded. It was agreed that President Ellsworth should instruct the chairman that the work of the committee was to be reviewed by the Research Planning Committee. This group would report on how the study should progress.

Mr. Pargellis reviewed the plan for a highly selective card bibliography (see January 29 minutes above). He reviewed the average reader's need for help in using huge, modern card catalogs, and the interest of the American Council of Learned Societies in the project. Some standard published bibliographies, such as the Guide $T_{0}$ Historical Literature would not be required if this project went through. On discussion it appeared that the cards would include some source material but mostly list secondary works. Each card annotation would tell why that title was included. The project would be useful both to the young undergraduate and to the Ph.D. working outside his specialty.

A danger of standardization in book purchasing was raised, as well as the desperate need for reader guidance felt in many libraries.

The financing of the initial work was to be borne mostly by a grant (to be sought) and the continuance paid for by subscriptions. It was felt the plan would be financially sound if several hundred subscriptions were secured. Differences between the plan and the Shaw List . . . as well as the U.S. Quarterly Book List were discussed. It was voted that, ACRL appoint two or three members of the group to work with Mr. Pargellis in developing his proposal for a selective, currently re- vised bibliography of those books most useful to the mature student, and in submitting it to whatever Councils or foundations the group wishes. (Note: Subsequently, Miss Gertrude Gscheidle, Mr. Morrison Haviland, and Mr. Herman Fussler were appointed to work on the project with $\mathrm{Mr}$. Pargellis and $\mathrm{Mr}$. Hamlin.)

President Ellsworth next reviewed the problem of ACRL finances. The new fiscal experiment proposed by ALA in 1950, had been tried by ACRL alone. This had resulted in a net loss to ACRL of approximately $\$ 1,600.00$. This year all divisions were, for the first time, on the new fiscal basis of support, and it looked as though ACRL's loss would be close to $\$ 3,000.00$. ACRL had as yet neither accepted nor rejected the plan for 1951/52. President Ellsworth had asked the ALA Executive Board to give the divisions some assurance that if additional income were derived from the increase in dues, a fair share of this increase would go to the divisions as well as to central activities. The ALA Executive Board had approved a recommendation of Mr. Clift to the effect that no immediate commitment should be made to change the formula. "At the end of the year if ALA's income from this source is out of proportion with that of the divisions, the Executive Board should consider some method which would turn back part of the increased income to the divisions."

Mr. Tauber spoke to the good faith of the Executive Board on this score and its need to be cautious. Mr. Ellsworth expressed fear that a desire to offer some additional central service might blind the Board to divisional needs. There is always a real danger that any extra funds will go into projects under the central ALA. The pressure is strong and constant at headquarters toward central services. The past history of ACRL's long struggle for recognition and funds was mentioned by several as a warning against too much faith and trust that adequate financial support would be provided.

It was noted several times that while the Executive Board had invited the divisions to discuss financial problems, its action had been taken before, and not after, discussion with the divisions. The ACRL president and executive secretary were requested to express to the Executive Board their pleasure at 
the opportunity to participate and express their views on divisional support.

Mr. Adams stressed the need for ACRL to learn from all this that it, too, can grow so large that the individual is lost, and that its sections and chapters should always be important as they reach the individual.

Mr. Lyle stated a need to stress that the $60 / 40$ per cent of the original proposal in I950 should be applied to the new dues scale so that $60 \%$ of all personal payments would go to the division. (The limit was held at $\$ 6.00$ under the new dues, which is only $30 \%$ of the top personal dues.)

It was recommended that the division go back to the old plan whereby ALA paid its office expenses and $20 \%$ of membership dues, as required by the By-Laws. This seemed the only course since the whole nature of the $60 / 40$ plan was negated by setting a $\$ 6.00$ limit on payment to a division for any one membership. After further discussion it was voted that, the board agrees on the desirability of continuing with the $60 / 40$ formula providing the formula is applied to all levels of personal dues above \$3.0o. The Board prefers that position unless the ALA Executive Board can develop a simpler formula that will assure each division of more favorable financial support for current needs. The board wishes institutional dues to be handled on the same principle it recommends for personal dues.

It was requested that the minutes appearing in College and Research Libraries should make it perfectly clear that sixty per cent of a dues payment did not go to the division of choice when the dues went above $\$ 10.00$ or below $\$ 6.00$. Sixty per cent was paid only for payments in the $\$ 6.00-\$ 10.00$ range. For example, in a payment of $\$ 20.00, \$ 14.00$ goes to ALA and $\$ 6.00$ to the division of choice.

$\mathrm{Mr}$. Hamlin was pressed for opinion on the effect of "old plan" versus "new plan" on his office. He was against going back and hoped his attitude would not cost ACRL \$2,700.00 in support which it would otherwise normally have. Progress was not made at Headquarters by fighting, and by pursuing a lone course. He felt acceptance of the new plan would make for better working relationships. The university leaders sitting on the Executive Board should be trusted to see that justice was done. It was voted that, in accepting for $1951 / 52$ the present experimental fiscal policy plan, this board expresses its confidence in the good faith of the ALA Executive Board to provide more adequately for the divisions later this year.

The question of a business manager for College and Research Libraries was raised and left to the editor and executive secretary for investigation.

It was voted that, the ACRL drop its membership in the American Council on Education and rely on its parent association, the ALA, to keep it in contact with this organization; also that, the budget allotted to the ACRL Audio-Visual Committee be increased to \$100.00; also that, the budget allotted to the Junior College Libraries Section of ACRL be increased to $\$ 75.00$.

-Arthur T. Hamlin, Executive Secretary.

\section{Pre-Conference Institutes at Columbia University}

The School of Library Service at Columbia University is scheduling three pre-conference institutes for June 24-28, 1952. Of interest to chief librarians and administrative officers interested in critical study of library management is the institute on Management Research and Improvement in Libraries. The development of library educational programs will be considered in a second institute on Strengthening Educational Service in Public Libraries, co-sponsored by the School and the Division of Public Libraries Committee on Adult Education and the ALA Adult Education Board.
The ALA Division of Cataloging and Classification is co-sponsoring an institute on Subject Analysis of Library Materials. Papers by specialists in these fields and group discussions of problems and methods will be featured. Meetings will be held on the Columbia campus, and the fee for each institute has been set at $\$ 27.00$. Dormitory accommodations are available at moderate cost. For information address the Dean, School of Library Service, Columbia University, New York 27, New York. 


\section{ACRL Study of Circulation Control}

During the past year the Association of College and Reference Libraries appointed a research planning committee which has as its function the designation of areas in which it is advisable to do research in order to reduce many of the problems which we are currently facing in college and university librarianship. For its first project the committee chose the problem of circulation control in college and research libraries. It is now in the process of synthesizing and evaluating the present knowledge of this field in an attempt to identify unsolved problems and indicate where further studies are desirable and practical in this area.

The committee is asking librarians all over the country who may have made innovations on well known circulation control systems or devised new systems to meet needs of their particular libraries, but have not published information on them to send write-ups of these systems to the undersigned. It is particularly interested in minor variations of standard patterns which have been worked out for college and research libraries as a means of simplifying systems that are generally known. The more detailed the write-up, the more value it will have to the committee. If any library is unable to supply this information in the near future, but will be glad to send it at some later date, the committee would be grateful for a letter to that effect. Such information will be of value to the committee in its initial project. Please send information to Forrest F. Carhart, Jr., assistant director of libraries, University of Denver, Denver 10, Colorado.

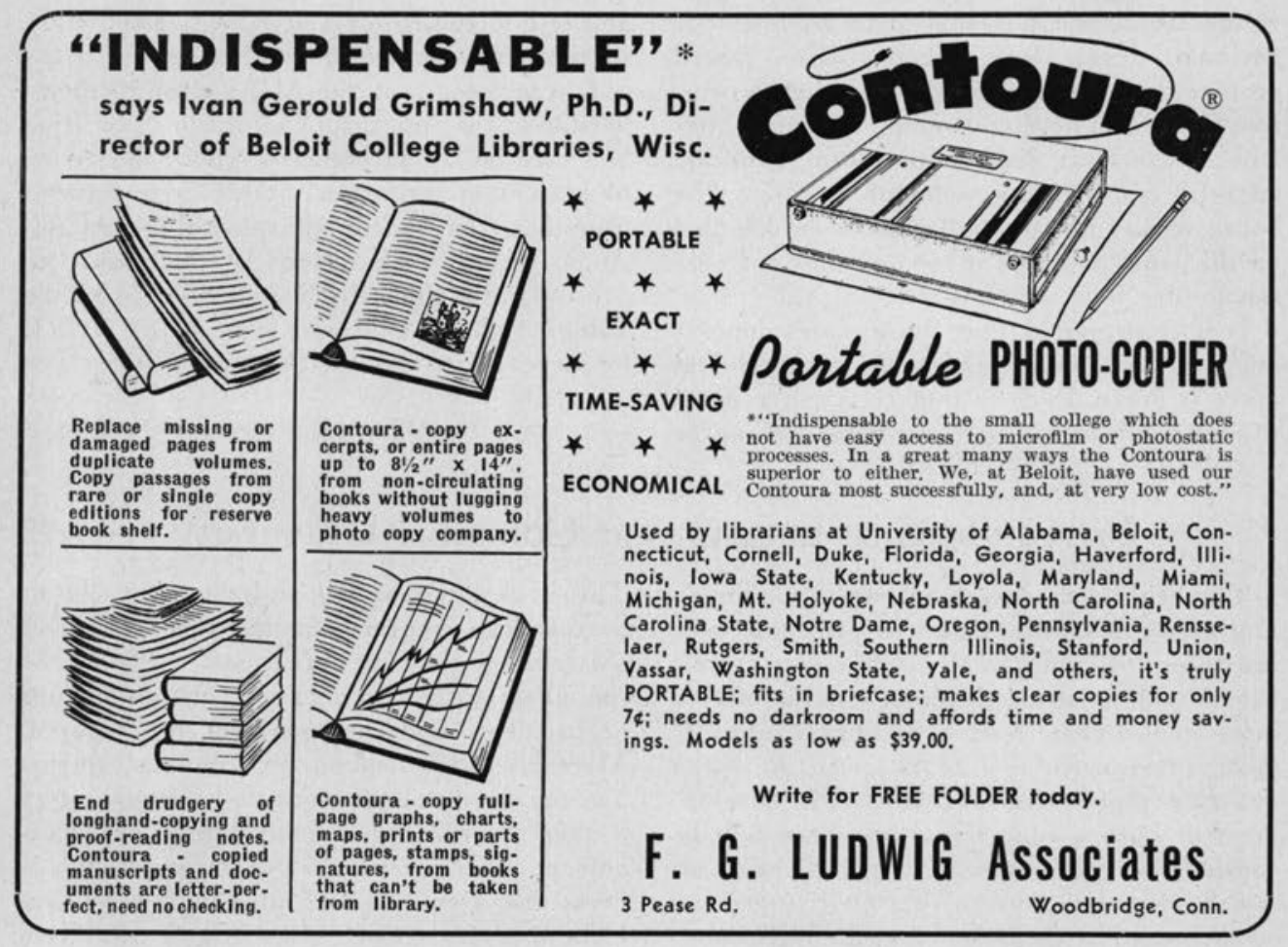




\section{Two Studies Proposed by ARL}

Dr. Frederick H. Wagman, of the Library of Congress, reports on the following proposals for investigation of problems of interest to college and reference librarians:

I. Standardization of Subject Headings

As has been remarked previously we are becoming increasingly dependent both for intelligence information regarding certain areas of the world and for news of recent scientific developments on minor publications and on interim research reports. Very often, authorship or title are of little utility as controls over such works. Frequently, these publications should be available and in use long before they can be cited in secondary sources or in bibliographies and the approach to such literature is primarily by subject. At present there is no list of subject headings adequate to the needs of both general and special libraries, nor is there any single agency capable of developing such a list without help. The research libraries continue to catalog monographs (as they must) but many special libraries are concerned almost entirely with publications at the level of journal articles and need far more detailed headings which may never find use in a large research library. The scientific documentation agencies of the Government have gone off on their own in developing subject headings useful in their work and among special libraries new subject heading lists proliferate.

Obviously it would be both wrong and impossible to exact from all libraries conformity to a universal list of headings even if such a list could be devised. The present tendency, however, leads to waste, unnecessary duplication of effort, and the development of bibliographic controls which cannot be integrated. Differences of subject heading treatment usually result less from profound differences of principle than from such considerations as the cost of revision of older work, or the fact that certain modifiers necessary in diverse catalogs become ridiculous in specialized ones. Only rarely does the need for detailed headings per se raise any problems. If the principles observed in the subject cataloging are the same, the headings used by a library cataloging periodical literature in economics and one cataloging only monographs should be easily integrable.

It should be possible to secure agreement on principles to be followed in the establishment of subject headings and to make the work of many institutions which follow those accepted principles useful to all by central publication of new headings established. It is proposed that there be a series of symposia aimed at elucidating the acceptable principles of subject cataloging, illuminating the problems in subject analysis of various kinds of publications, and securing as wide agreement as possible on principles. If such agreement can be achieved, the next step will be to determine concretely how the work of each library can be made useful to all others. It is recommended that the problem of arranging for such symposia be referred to the Board on Cataloging Policy and Research of the ALA Division- of Cataloging and Classification.

\section{High Costs Involved in Transfer of Collections}

The establishment of the Midwest Interlibrary Center and of an analogous institution at Mt. Holyoke College for college libraries in the vicinity as well as current discussions regarding development of a northeastern interlibrary center all raise the possibility that the future will see an increasing number of poolings or transfers of collections. Cooperation by the research libraries in a national program involving division of responsibility for developing and maintaining collections of publications from the little-known countries of the world would conceivably involve additional transfers. Such transfers are accompanied by relatively high costs incurred in changing existing catalog records, making new ones, relabeling, etc. Indeed, it is frequently, and correctly, alleged that these costs are high when books are transferred between libraries which use the same classification or even from one part of a library to another division of the same institution. It would be well, for the future, to inquire into the ramifications of this problem and examine all possibilities of standardization which might permit research libraries to incorporate transferred books into their collections, or to pool collections with minimum expense. It is recommended that this question also be presented to the Board on Cataloging Policy and Research for study. 


\section{News from the Field}

Acquisitions, Gifts, Collections

One of the world's greatest libraries on the polar regions has been placed on deposit in the Baker Library at Dartmouth College. Assembled by the famous explorer Vilhjalmur Stefansson over a period of forty years, the collection contains 25,000 volumes, 20,000 pamphlets, and many manuscripts. The collection covers the history, science, music, linguistics and folklore of the Arctic, Antarctic, and permafrost areas of the world. A valuable reference library for scholars, the collection has been used extensively by Dr. Stefansson in the compilation of his Encyclopedia Antarctica which is now being completed. The collection is available for use by Dartmouth students and faculty and other scholars upon application.

The University of Wyoming Library has received a gift of over 700 items of Western Americana from William Robertson Coe of New York City. The gift includes books and pamphlets published from an early date up to the present time. Some of these items were originally from the library of the Right Reverend Nathaniel S. Thomas, one time bishop of Wyoming who was a collector of western books.

The University of Pittsburgh Library has received seventy-five thousand dollars from the Hartman Estate as directed by the will of Galen C. Hartman, a life-time resident of Pittsburgh and a distinguished member of the Allegheny County Bar. Under the terms of the will, books purchased with the gift are to be in the English language and non-technical in subject matter.

The Michael Sadleir collection of Victorian England novels and other British fiction of the nineteenth century has been acquired by the University of California Library in Los Angeles. The twelve thousand volume collection was purchased with special funds made available by the University. The collection represents a life-time of book collecting by Michael Sadleir, a partner in the British publishing house of Constable. Mr. Sadleir, in addition to being one of England's most learned bibliographers, is also the author of several novels, including Fanny by Gaslight.
The collection is described as providing invaluable assistance in the study of the literary taste and social history of the Victorian period.

Mr. Edward A. Holter of San Francisco recently donated a large manuscript collection on the western and southern lumber industry to Cornell University. The papers are those of Henry W. Sage, nineteenth century lumber figure, and those of the Sage Land and Lumber Company which he founded. The collection includes business letters, journals, account books, deeds, and other personal papers. Henry W. Sage made many valuable contributions to Cornell during his life and the Sage family's benefaction made it the most generous of all donors to Cornell in the nineteenth century.

\section{Awards, Prizes, Scholarships}

The Bollingen Prize in Poetry of the Yale University Library was granted to Marianne Moore for 1951. W. H. Auden, Chairman of the Bollingen Committee, said that Miss Moore received the award for her most recent volume, Collected Poems. Under the terms of the gift, the one thousand dollar prize may be given to a poet for a book published in the preceding year or in consideration of the poet's entire work. Recipient of the Bollingen award in 1950 was John Crowe Ransom, and Wallace Stevens was the winner in 1949.

Miss Moore was born in St. Louis and received her B.A. degree from Bryn Mawr College. She taught at the Carlisle Indian School from I9II to 1915. She was employed as an assistant at the New York Public Library from 1921 to 1925 , and was acting editor of The Dial from 1925 to I929. Miss Moore's excellence as a poet has been noted officially many times in the past.

The Folger Library is offering two $\$ 1000$ book prizes for the purpose of encouraging creative scholarship in the field of English civilization for the sixteenth and seventeenth centuries, and to encourage the study of the literature, drama and theatre, especially that dealing with Shakespeare. The prizes will be awarded for the two best book-length manuscripts submitted for publication. One requirement is that a substantial portion of the 
research upon the books submitted must have been carried on in the Folger Library. One prize of $\$ 1000$ will be offered for the best manuscript submitted in the history of English civilization in the period between 1500 and 1700 . Books dealing with any aspect of the cultural history of this period will be eligible. Manuscripts for the contests should be sent to the Director of the Folger Library not later than October I, 1953. The other prize of $\$ 1000$ will be offered for the best manuscript submitted in the field of English literature of the sixteenth and seventeenth centuries, or in the history of the English drama and theatre of the eighteenth century, or in the interpretation of Shakespeare, and the history of his reputation and the performance of his plays in any period. Manuscripts in this contest should be sent to the Director of the Folger Library, Washington 3, D.C., not later than October I, 1954. Louis B. Wright, Director of the Folger Library, has stated that another purpose of the awards is to stimulate non-pedantic scholarship. "We hope that scholars working in the Folger Library will produce works of interpretation or contributions to knowledge which have vitality, revelance, and genuine significance, so well written that these books will be read by others besides specialists in the field."

\section{Miscellaneous}

Alpha Beta Alpha, the national coeducational undergraduate Library Science Fraternity, held its first biennial convention on the campus of Northwestern State College, Natchitoches, La., on March 15 and 16.

Following a recent survey of the Dillard University Library, New Orleans, the General Education Board offered $\$ 25,000$ to help expand the book collection if the University matches this sum. The total fifty thousand dollars once raised, the University secured the services of Mr. William H. Carlson as a special consultant to direct the book purchasing program. Mr. Carlson, the Director of Libraries of the Oregon State System of Higher Education, spent three months (October-December) on the Dillard campus.

The purpose of this project is not only to enlarge the collection, but to give added depth and richness to the library.

A $16 \mathrm{~mm}$ black and white sound film (390 feet) on the Bollinger Lincoln collection has recently been released by the State University of Iowa Libraries.

Nearly four thousand volumes, many of them extremely rare, relating to the life of Abraham Lincoln were brought together by the late Judge James W. Bollinger of Davenport, Iowa, during his lifetime, and donated to the State University of Iowa.

Late in 1951, many of the nation's foremost collectors and authors of books relating to Lincoln, gathered on the University campus in Iowa City to participate in the dedication of the Bollinger collection. The group discusses the various features of the collection, and the film shows some of the many foreign language editions of the life of Lincoln, some of the special books in the collection, and the photographs and small mementoes.

A few of the other special collections in the University Library, including the Leigh Hunt collection, the Springer library of printing and typography, and the collection of books by Iowa authors are shown.

Professor Ralph Ellsworth, Director of University Libraries, reviews the University's attitude toward these special collections, and summarizes their value in the University $\mathrm{Li}$ brary system.

Note: This film and the music has been cleared for television. On release it was distributed through Information Service to a number of TV stations in December, 1951, and January, 1952. Sale price, \$40.00. Rental price, \$1.25.

The Midwest Inter-Library Center is now in full operation. On December 7 the first books of the Center's rapidly growing collection were moved into the newly completed fourth tier of its bookstacks. The first request for a book was received on the same day. The University of Minnesota, a member institution, requested a Leipzig University dissertation published in 1932 . The desired item had been found and air-mailed to Minnesota within an hour. A few days later, 8500 cata$\log$ cards were mailed to the fifteen participating institutions along with generalized descriptions of the Center's collections of newspapers, dissertations, college catalogs, and text books. These descriptions and catalog cards give the member institutions full information concerning material available in the Midwest Inter-Library Center. 
The New York State Publications

School of Industrial and Labor Relations at Cornell University has published Manpower, Wages, and Labor Relations in $W$ orld $W$ ar $I I$, an annotated bibliography of materials published on American industrial mobilization experience during the war. The ninety-three page bulletin lists and gives brief descriptions of more than four hundred books, articles, pamphlets, government publications and periodicals that dealt with problems of manpower mobilization and utilization, wage stabilization and labor relations. The Bulletin may be obtained from the Distribution Center, New York State School of Industrial and Labor Relations, Ithaca, New York. Single copies are free to residents of New York State. A charge of twenty-five cents per copy is made for bulk orders and for requests from outside the state.

The new edition of the Racine Public Library Staff Manual is both informative and well written.

The Development of Library Resources at Northwestern University is the title of the February 1952 issue in the University of Illinois Library School's series of Occasional Papers. It was written by William V. Jackson last year, when he was a student at the Library School. The paper discusses the Libraries on both the Evanston and Chicago campuses of Northwestern, traces their history briefly, and considers the strength of the collection in various subject fields. A copy may be obtained free of charge. Address all communications to Editor, Occasional Papers, University of Illinois Library School, Urbana, Illinois. Any library may receive a copy of each issue in the series if a request is made to this effect.

Marion L. Goodwin, Librarian, Keene Teachers College, Keene, New Hampshire, has prepared in manuscript a study of " $\mathrm{Li}$ braries in Small Teachers' Colleges." The study includes data of $\mathrm{I}$. amount of service, 2. status of the librarian, 3. the extent of librarians' work in training schools of the colleges, and 4. financial support of the libraries. The study is available for loan from ACRL Headquarters, American Library Association, 50 East Huron Street, Chicago II, Illinois.

Among recent Library of Congress bibliographical publications prepared in the Ref- erence Department are Serial Publications of the Soviet Union, 1939-1951: A Preliminary Checklist prepared by Rudolf Smits (special supplement to Monthly List of Russian Accessions, $316 \mathrm{p}$. \$1.50, order from Superintendent of Documents; $A$ Guide to Dutch Bibliographies prepared by Bertus H. Wabeke, 193p. \$1.30; Manchuria compiled by Peter A. Berton, 187p. \$1.30; Iran compiled by Hafez F. Farman, roop. $70 \phi ;$ The Arabian Peninsula prepared under the direction of the Near East Section, Division of Orientalia, I I Ip. $80 \phi$; American History and Civilization 2nd. revised edition compiled by Donald $H$. Mugridge (18p. 25 $\dot{\text { }}$ ). The last five items are to be ordered from the Card Division, Library of Congress.

The Hotchkiss Map Collection is a Library of Congress publication with three hundred and forty-one entries prepared by Clara E. LeGear at $60 \phi$.

Librarians interested in book selection will find informative Book Selection Policies and Procedures edited by Marion E. Hawes and Dorothy Sinclair and issued by the Enoch Pratt Free Library, Baltimore. Part I considers "Policies," and Part II "Principles of Selection in Specific Areas."

Gonzalo Valazquez is the compiler of Anuario Bibliografico Puertorriqueno 1949 which is issued by the Biblioteca de la Universidad, Rio Piedras, P. R. (I95 I, 83p.)

Alberto Villalon is the editor of a series Bibliografias y Lecturas Bibliotecnicas of which the first number, Serie A, is Organizacion y Administracion de Bibliotecas 49p. 1950. Five other parts are planned.

Trinity College, Hartford, Conn., has published the fourth edition of Books for a College Student's Reading by Professor Harry Todd Costello (1951, 92p. \$1.0o.)

The Curriculum Bulletin edited by Hugh B. Wood at the School of Education, University of Oregon, Eugene, continues to contain issues of special usefulness to librarians, particularly those of teachers colleges. Among the titles issued are "Bibliography of Bibliographies of Instructional Aids to Learning" prepared by Elizabeth Findly, 50ф and a "Bibliography of General Courses of Study and Guides," $20 \dot{\phi}$. Also published are bibliographies of curriculum materials in the following fields: "Social Studies," 20 $\dot{\phi}$; "Science," $15 \dot{\phi}$; "Language Arts and Foreign Languages," 20 $\dot{\phi}$; "Health and 
Physical Education," I5 $\dot{\text {; }}$ "Mathematics," $15 \dot{c}$; "Fine and Industrial Arts and Crafts," $20 \phi$ and "Homemaking," ${ }^{5} \phi$. Additional titles of interest include: "Teacher Education in Oregon-An Opinion Survey," 25 $\dot{\text {; }}$ "In Service Education of Teachers, an Evaluation," 40 $\dot{\text {; }}$ "Improving College Teaching," $60 c$. Issued recently in revised form are "Sources of Free and Inexpensive Teaching Materials," $65 \phi$ and "Sources of Free and Inexpensive Materials in Social Studies," $30 \phi$. Similar bulletins have covered "Health and Physical Education," $20 \phi$ and "Science," I5 $\dot{\phi}$. The annual subscription price is $\$ 5.00$, about twenty-five per cent less than the list price of the individual bulletins. About twenty to twenty-five bulletins are issued annually. Address Curriculum Bulletin, University of Oregon, Eugene, Oregon.

The National Archives has issued a List of File Microcopies of the National Archives, Washington, D.C. (1950, 67p.). This list which supersedes an earlier list published by the National Archives in 1947, includes three thousand four hundred and seventy-eight rolls of $35 \mathrm{~mm}$. master negatives, containing reproductions of more than two million pages. Positive prints of one or more rolls of a file microcopy are available at a cost of $\$ 4.00$ for each fifty feet of film to the nearest fifty feet, the cost to be calculated on the total footage of each order.

Dr. Judson B. Gilbert is the compiler of A Bibliography of Articles on the History of American Medicine Compiled From "Writings on American History" 1902-1937 published by the New York Academy of Medicine (195I, 44p. \$1.25.) This work supplements the bibliography of history which is published annually in the Bulletin of the History of Medicine.

The Scarecrow Press has published the second edition, revised and enlarged, of Index to Plays in Collections by John H. Ottemiller (195I, 386p. \$6.50). This author and title index to plays appearing in collections published between 1900 and 1950 is an enlarged version of the first edition which appeared in 1943. It now indexes four thousand nine hundred and thirty-three plays by nine hundred and eighty-four different authors, involving four hundred and sixty-three collections. As George Freedley comments in the preface: "Its value to the librarian is now a proven actuality and no longer something which he had to speculate about as a reference tool."

Another publication of the Scarecrow Press is Acres of Flint: Writers of Rural New England, 1870-1900, by Perry D. Westbrook (1951, 199p. \$4.00). Among the writers discussed are John Greenleaf Whittier, Harriet Beecher Stowe, Rowland E. Robinson, Sarah Orne Jewett, Helen Hunt Jackson, Alice Brown, Rose Terry Cooke, Mary Wilkins Freeman, Celia Thaxter, and Lucy Larcom.

Dr. Seymour S. Weiner, a student in the Columbia School of Library Service, is the author of Francis Carco; The Career of a Literary Bohemian, New York, Columbia University Press, 1952. (xvi, 274p. illustrated \$4.0o.) This is the first extensive study in any language of the contemporary French poet and novelist. Combining biography with critical appreciation of Carco's literary output, Dr. Weiner also examines his personality, literary affiliations, and interests, which illuminate a modern aspect of the bohemian tradition. Numerous caricatures, photographs, portraits, and illustrations for Carco's works are reproduced. Carco, who won the Grand Prix of the French Academy, is a member of the Goncourt Academy and on the Board of Directors of the National Committee of Writers.

The Library Quarterly in its July and October 195I issues contains articles by Carl W. Hintz on "Notable Materials Added to North American Libraries 1948-49." The October issue also includes "Graduate Theses Accepted by Library Schools in the United States I950-5I" by Leon Carnovsky.

Sagas of Struggle, A Labor Anthology selected by Samuel Colton, New York, Claridge Publishing Corporation, I951, I28p. \$2.25, is a collection of short pieces dealing with the problems of labor.

An Annotated Reading List for Prospcctive Lawyers 1951, 71p., has been issued by the New York University School of Law, Washington Square, New York.

The Library Association, Chaucer House, Malet Place, London, W.C. I, has issued the following three items in its "Pamphlet" series: No. 6, A Mental Hospital Library by Kathleen M. Allsop, 195I, 44p; No. 7, Prison Libraries by R. F. Watson 195I, 45p. and No. 8, Children's Periodicals of the Nineteenth Century by Sheila A. Egoff 1951, 55p. Each 
is priced at 5s. (3s. 6d. to members). The Association has also released The Year's Work in Librarianship, vol. XIV, 1947 (195 I, 337p.) edited by W. A. Munford. As with previous volumes in this series, an effort is made to cover a variety of aspects of librarianship as revealed in both English and other professional journals. Since the material covers the year 1947 (the volume having been interrupted by World War II), the material may not be as fresh to readers as the editor and writers would like. However, it serves a useful purpose in bringing together observations on the accomplishments and literature of the year in question. (30s.-22s. 6d. to members).

The first number of News Sheet has been issued by the newly organized Pure and Applied Sciences Section of ACRL. This publication will contain information of interest to all members of this new section.

Uranium and Its Compounds; a Bibliography of Unclassified Literature compiled by Fred E. Croxton, Oak Ridge, Tenn., Carbide and Carbon Chemical Company 195I, Report No. K-295, part 2, includes three thousand nine hundred and seventy references to the unclassified literature on uranium published between 1789 and 1950. Author, subject and report or patent number indexes to the chronological record are included, and brief annotations or abstracts given for most of the items.
The Special Libraries Association has issued a new Directory of Members (as of March Io, 195I), including almost five thousand names, 296p. \$4.oo.

The Special Libraries Council of Philadelphia and Vicinity has published a Directory of Libraries and Information Sources in the Philadelphia Area, edited by Mrs. Rebecca B. Monego (1951, 128p., \$2.25, order from Mrs. Monego, 5I E. Garfield St., Philadelphia 44, Pa.)

Author Headings for the Official Publications of the State of Wyoming (American Library Association, 1951, 60p., $\$ 1.50)$ is another in the list of such compilations of state author entries. It is a useful tool for catalogers.

The Theodosian Code and Novels and the Sirmondian Constitutions, a translation with commentary, glossary, and bibliography, by Clyde Pharr, in collaboration with Theresa Sherrer Davidson and Mary Brown Pharr (Princeton University Press, 1952, 643p., \$20.00) is volume I of The Corpus of Roman Law (Corpus Juris Romani). This work is intended to be a translation, with commentary, of all the source material of Roman law. The Theodosian Code contains laws which are similar to those involving modern problems of society-price fixing, black markets, socialized medicine, state controls, etc. It should serve as a useful reference source for workers in the social sciences generally.

\section{A Political Scientist in the Reference Library}

\section{(Continued from page 143)}

York Times and I had found descriptions of them in various other places, but I wanted the constitutions themselves. She said, "Have you looked in the United Nations Yearbook on Human Rights for 1947?" I had not looked there. When I did, I found sections of the various constitutions that dealt with human rights. Much more important, however, there were footnotes acknowledging information on constitutions from legations and embassies of satellite countries-the sort of information that made it possible for me to write for copies of the various constitutions.
Since that time, this material has been conveniently presented in Amos J. Peaslee's Constitutions of the Nations.

Judging from my own experiences, I feel that the political scientist of some experience does not expect from the reference librarian help on the body of the material, but on the all important and often incredibly elusive peripheral details. He hopes for information about the newer bibliographies that he has not yet met, and for leads in outside fields-leads that will take him to the amazingly concealed facts which his own research would not uncover. 


\section{Personnel}

Apointment of John E. Pomfret as director of the Henry E. Huntington Library and Art Gallery is welcome news to

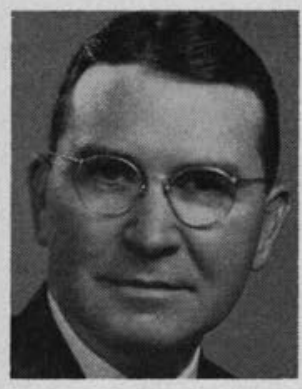

John E. Pomfret scholars everywhere, especially to those whose fields of investigation are within the range of this great collection. The trustees, in announcing the choice of $\mathrm{Mr}$. Pomfret, emphasize once more their primary concern to be with scholarship. In support of their desire to advance studies in Anglo-American civilization and in the cultures of the American continents, they have had help from many individual donors and from foundations. Purchases and gifts add steadily to the stock of rare books and documents gathered by the founder. Awards of fellowships are in keeping with the opportunities for research. These are available for a limited number of advanced scholars. Workers at the Library have come mainly from Canada, Great Britain, and the United States, to carry to completion or to explore certain phases of definitive studies in the history of the Renaissance and in those sectors of American history and culture which are represented by its holdings.

Mr. Pomfret centered his teaching and research on early American history from the beginning of his work at Princeton University in 1925. Following his twelve years on the Princeton faculty, he carried the duties of graduate dean at Vanderbilt University as well as his specific research and teaching in history. He was released for a time by both Princeton and Vanderbilt to serve the Social Science Research Council as fellowship secretary. In 1942 he became president of the College of William and Mary. Through his efforts the Institute of Early American History was created under the joint sponsorship of the College and Colonial Williamsburg. The William and Mary Quarterly, a publication of the Institute, was placed on its present high level of service to scholars and general readers by virtue of its unusual articles and reviews on American historical subjects. Through these activities and as a member of the Senate of Phi Beta Kappa, Mr. Pomfret has a wide range of acquaintance among the personnel of his own and related fields. His most recent publications are on the early history of New Jersey; in his new post he will carry on his own research with his administrative duties.

Since the retirement of Max Farrand as director of research in 1941, guidance of research and administration of the institution has been by committees working under the direction of its board of five trustees headed by Dr. Robert A. Millikan. The short incumbency of Mr. J. E. Wallace Sterling as director in 1949, ended by his election to the presidency of Stanford University, was the only variation from such operation by a small group of scholars. Their work developed a sound program of research and publication. Among scholars here and abroad, the contributions of these men are known to have created the current Huntington tradition; namely, Edwin F. Gay, Louis B. Wright, Dixon Wecter, C. H. Collins Baker, Robert G. Cleland, and Godfrey Davies. The two last named are in charge of work in American history, with emphasis on the Southwest, and of studies in British history of the later Renaissance. Since the departure of Mr. Wright to become the director of the Folger Library, Mr. Davies has served also as editor of the Quarterly. Throughout the period since its opening, the staffs of the several departments under the Librarian, Leslie E. Bliss, have kept the Library functioning efficiently and well provided with reference works essential to scholarly research.

The organization which Mr. Pomfret is to direct also includes personnel to maintain the extensive gardens, to prepare public exhibitions of rare books and manuscripts, and to make the Art Gallery an attraction to increasing numbers of visitors. He began his duties on November 1.-David H. Stevens.

J Tlliam G. Harkins assumed duties as Librarian of the College of William and Mary on December 17, 1951. 
Mr. Harkins has had wide experience in library administration; since 1940 he has been librarian of the University of Miami.

A native of Macon, Mississippi, Mr. Harkins was graduated with a B.A. degree from the University of Alabama in 1932. The next year he was awarded a professional library science degree, B.S. in Library Science, by the University of Illinois; he holds also a graduate degree, M.A. in Library Science, from the University of Michigan. $\mathrm{He}$ has completed several quarters of study leading to the $\mathrm{Ph} . \mathrm{D}$. degree at the Graduate Library School of the University of Chicago.

Before going to the University of Miami, Mr. Harkins held variously the positions of medical librarian, cataloger, head cataloger and assistant librarian at one or the other of the Universities of Mississippi and Alabama. $\mathrm{He}$ was granted military leave by the University of Miami to serve in the Air Force during World War II.

$\mathrm{E}$ Dard C. Heintz, formerly assistant librarian at Bowdoin College Library, Brunswick, Maine, is the new head librarian

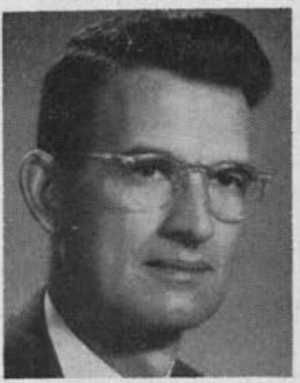

Edward C. Heintz at Kenyon College, Gambier, Ohio. Mr. Heintz, who graduated cum laude from Brown University, received his library training at the University of Michigan.

Except for the war years, during which he was employed in group leader training at Pratt and Whitney Aircraft, East Hartford, Conn., Mr. Heintz has been engaged in library work since 1938. He has gathered experience in such libraries as the Public Library, Springfield, Mass.; State University of Iowa, Iowa City; Brown University, and since 1946 Bowdoin College. He has also published several articles in library journals.

Mr. Heintz started his duties at Kenyon College on February I, 1952.

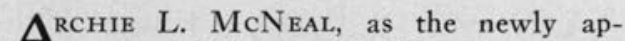
$A$ pointed Director of Libraries at the University of Miami, will be in an excellent

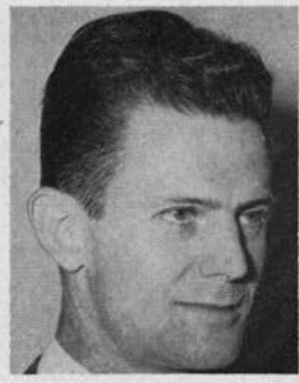

Archie L. McNeal position to put into practice his many and carefully thought through ideas on university library administration. In his three and a half years at the University of Tennessee he demonstrated an unusual ability to work successfully with the University faculty in his capacity as Chief of Readers' Services Division, a member of many University committees, a full professor, an elected member of the Senate, and as President of the University Faculty Club. From the U-T librarians' point of view, one of his most important contributions was made as a member of a committee which initiated a successful effort to obtain faculty rank for members of the professional library staff. His fundamental belief in the value and dignity of the library profession probably foretells certain areas of activity which can be expected at not only the University of Miami and in the Southeastern region but also in the profession at large. This type of interest and activity is characteristic of Dr. McNeal, for in almost every professional problem he attempts to solve he holds constantly in mind the relationship of the immediate problem to that of the total profession and of the total field of library economy. This universality of approach has been one of the most healthful influences upon the rest of us at U-T, and faculty and librarians at the University of Miami, as well as other librarians in Florida, will probably find this quality to be of considerable value to them in their future contacts with him.

Dr. McNeal began his library experience at Cossitt Library in Memphis as a page, from I931 to 1932, then served as Reference Assistant from 1932 to 1934 . From 1934 to 1936 he was librarian of a Shelby County high school, during which period he completed his B.S. in L.S. degree at Peabody. Appointment as librarian of East Tennessee State College followed, and his work there continued from 1936 to 1948 , with an interruption of three years for war service, $1943-46$, as a communications officer with the Far East Air Forces. He joined the University of Ten- 
nessee Library staff September 1948 and resigned February I, 1952, the date of his appointment as Director of the University of Miami Libraries. While at the University of Tennessee he completed, during summer quarters, his residence on his Ph.D. in library science at the University of Chicago, receiving his degree in August 195I. The subject of his dissertation is "Rural Reading Interests: Needs Related to Availability." He participated in the conference on rural reading con- vened in Washington September I95I under the auspices of the United States Department of Agriculture.

Other professional activities have included service as president of the Tennessee Library Association, 1940-42, member of the Committee on Constitution and By-Laws for ACRL, 1949-52, member ALA Council, 194I. $\mathrm{He}$ has also been active in the Southeastern Library Association since 1936.-William $H$. Jesse.

\section{Appointments}

Lemoyne W. Anderson and Mrs. Thelma C. Bird have been appointed library advisors in the University of Illinois Chicago Undergraduate Division Library's newly-established Department of Library Instruction and Advisement.

Helen L. Andrews is head cataloger, University of Arkansas Library.

Mary Lee Bundy was appointed head of the Circulation Department, Rensselaer Polytechnic Institute Library, November Ist.

Norman Bursler, assistant professor and research associate of the University of Chicago School of Law since 1946 is now law librarian at the University of Chicago.

Additions to the staff of the Columbia University Libraries include Nathalie Chlan, Mary Cunningham, Mrs. Esther H. Easter, Florence Gitelson, Clare Marie Hegele, Mrs. Elizabeth C. Hillegas, Mrs. Bette Bartlett Klemt, Erich Meyerhoff, Paul R. Palmer, Mrs. Nyhla B. Strong, and J. Donald Thomas.

Laura Cummings has been appointed assistant catalog librarian in charge of the Serials Division, Columbia University Libraries.

Dartmouth College Library has announced the appointment of Harold G. Rugg as associate librarian, Virginia L. Close as reference librarian, William R. Lansberg as assistant to the librarian, Mrs. Theodore R. Clark, Barbara A. Monroe and Rae Welch as assistants in the Circulation Department, Mrs. Donald W. Clark as assistant in the Reserve Book Department, and Mrs. Robert L. Sanborn as assistant in the Catalog Department.

Ben C. Driver, formerly Chemistry-Physics
Librarian at Columbia University, is now Bio-Medical Librarian at the University of Chicago.

Dr. Leslie W. Dunlap is now associate director of libraries, public services, at the University of Illinois.

Robert W. Greenwood is now head of the Circulation Department at Tulane University's Howard-Tilton Memorial Library.

Earl E. Hoven is agricultural reference librarian, Texas $\mathrm{A}$. and $\mathrm{M}$. College Library.

Mrs. Irma Y. Johnson is economics librarian, Dewey Library, Massachusetts Institute of Technology.

Olive Johnson has been appointed assistant reference librarian, Columbia University $\mathrm{Li}$ braries.

Samuel E. Keeton is assistant librarian, Willamette University.

James Kingsley, former Biological-Medical Librarian at Minnesota, has been appointed head of the Acquisitions Department at that university.

Dr. Robert D. Leigh, Visiting Professor of Library Service at Columbia University and Director of the Communications Study of the Russell Sage Foundation, has been appointed to conduct a special survey of the possible need for establishing a school of librarianship at UCLA.

Irving Lieberman has been appointed research associate in charge of the Audio-Visual Project of the School of Librarianship, University of California.

Clara M. McFrancis is head of the catalog department at Texas A. and M. College Library.

Vera Makivirta has been appointed librarian of the Biological-Medical Library, Uni- 
versity of Minnesota.

Patricia McWhorter is head cataloger, Fisk University Library.

Eleanor Matthews has been appointed assistant librarian, Madison College, Harrisonburg, Va.

Mrs. Elizabeth K. Olmstead is circulation librarian, readers' division, Wellesley College Library.

Katherine Parkins is reference librarian, California State Polytechnic College, San Luis Obispo.

Fernando Peñalosa has been appointed to the staff at the Fresno State College Library, California.

Ransom L. Richardson is the new editor of the ALA Bulletin, succeeding M. Alice Dunlap, who resigned.

Mrs. Alta B. Rieck is assistant order librarian, Willamette University.

Tauno I. Salo is technical reference librarian, Montana State College.
Mildred Straka is now head of the catalog department, Smith College Library.

Syble E. Tatom is librarian, Graduate Center-Pharmacy Library, University of

Arkansas.

Gene E. Valk is now chief cataloger, Rensselaer Polytechnic Institute Library.

Robert Wadsworth has been appointed head of the Acquisitions Department, University of Chicago Library.

Mrs. Marian Reed Watts is now circulation librarian, Mary Washington College, Fredericksburg, Va.

Bertha B. Hallam, University of Oregon Medical School Librarian since 1919, was presented with a silver tea service and elevated to Honorary Membership in the Portland Academy of Medicine at their annual meeting and banquet, December 13th. Miss Hallam is one of four honorary members of the Portland Academy of Medicine and is the only woman ever to achieve such a distinction.

\section{Retirement of Edward A. Henry}

Because of reaching the age limit $\mathrm{Mr}$. Edward A. Henry was retired as librarian by the University of Cincinnati August 31, 1951. On September 16 he moved to Nashville, Tennessee, on a dual appointment. $\mathrm{He}$

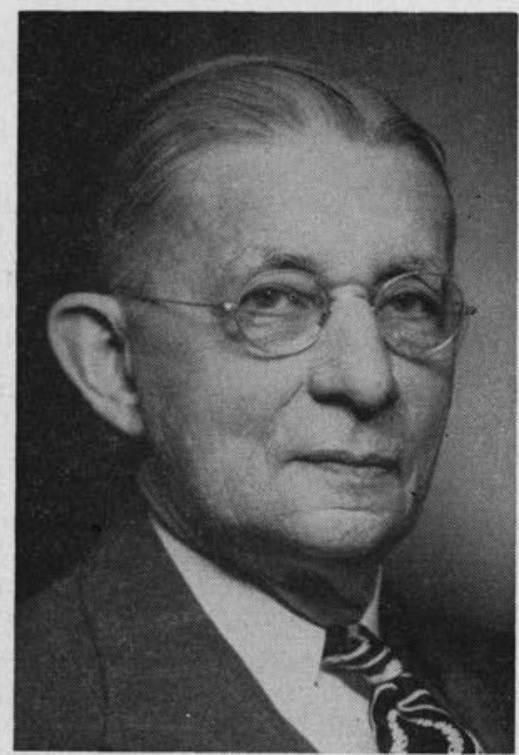

Edward A. Henry joined the staff of the Joint University $\mathrm{Li}$ braries as a senior cataloger and he will also be a part-time teacher in the Library School of George Peabody College.

At its first meeting in the Fall of $195 \mathrm{I}$ the McKickin College of Liberal Arts of the University of Cincinnati adopted the following resolution, prepared by Dr. M. J. Hubert, Chairman of the Faculty Advisory Committee of the Library:

Mr. Edward A. Henry joined the faculty at the University of Cincinnati in 1928 , coming to us from the University of Chicago after a distinguished career as a scholar in the fields of theology and of the history, culture, and languages of the Near East.

$\mathrm{He}$ had turned to library work as a career, but it should be mentioned here that his interest in the history and culture of the Orient remained vigorous and active at all times. $\mathrm{His}$ immediate task at Cincinnati was to give shape to our Library Building, and to guide the growth of its many collections. In 1928 this library, which many of us now take for granted, existed only as a project. It was $\mathrm{Mr}$. Henry who gave form and life to that project; he not only shaped its general design, he planned the larger portion of its detail, having always in mind the idea that it must serve the 
needs of the University for many decades. Its decoration, planned with loving care, must have given keen delight to one who cherishes books as he does. Those who have gone there to work and study will have noted in the chandeliers, the windows, and the bronze tablets, a series of proverbs in many languages, of early printers' devices, and of other symbolic representations of various phases of the great field of human knowledge.

Having made a library a charming and beautiful home for books, Mr. Henry presided over a phenomenal growth in the collections housed therein. When he arrived we owned about 187,000 volumes; when he left that number had grown to 660,000 . In the twenty-three years of his administration the small college library which he found in the old Van Wormer Building has been transformed into a great university library of which we may well be proud. The staff, too, has more than doubled, and it is a pleasure to note that most of the books which had been catalogued on the Dewey system have been recatalogued to conform with the now universally used Library of Congress plan.

We in the College of Liberal Arts have particular reason to value Mr. Henry's contribution to the educational task in which we all participate. Each year he has instructed large sections of freshman students in the proper and effective use of our collection of books. He has frequently taught one semester of our regular course in biblical literature. $\mathrm{He}$ has lectured many times before various groups in the city on writing, old books, oriental contributions to modern culture, always without charge, as a contribution of the university to the community. $\mathrm{He}$ has given his time and energy to a host of valuable scholarly projects, far more of them indeed than can be enumerated here. I can only mention in passing such tasks as the editorship of College and Reference Library Year Books in the thirties, and Doctoral Dissertations Acceptable by American Universities in the early forties, as well as his pioneering work in the field of micro-films. Our membership in the extremely valuable Midwest Inter-Library Center is due to his labor and foresight.

Mr. Henry has served the University well. Our College of Liberal Arts uses, perhaps more than any other unit of the University, both the structure and the collection that were built up during his administration. We congratulate him on work well done and we wish him long life and happiness in his new home.

\section{Necrology}

Robert Wilson Christ, assistant librarian of Duke University, died in the Duke University Hospital on December 23, I95I after a brief

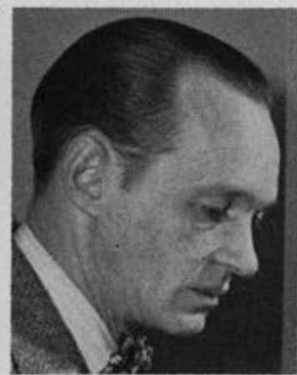

Robert Wilson Christ illness. He was 43 years old.

Christ joined the Duke staff, as assista n $\mathrm{t}$ i b r a r i n in charge of readers' services, in February, 1948. Before coming to Durham he had served as Chief of the Information Section, Reference Division, Department of State; Reference Librarian, Grosvenor Library, Buffalo, New York; acting librarian, Lending Service Library, Columbia University; and assistant to the librarian, Mount Holyoke College. He received an A.B. degree cum laude from Am- herst in 1930, and an M.S. degree from the School of Library Service, Columbia University, in 1948 .

Bob Christ was an active member of his professional library associations. He had served as president of the Western New York chapter of the Special Libraries Association; chairman of Reference Section of the Association of College and Reference Libraries; national chairman of the Public Relations Committee of the Special Libraries Association; on important committees of the North Carolina, Southeastern, Special, and American Library Associations; and at the time of his death was a member of the Council of the American Library Association. He taught in the library school of the Florida State University in the summer of 1949 and at Syracuse University last summer.

The range of his scholarly interests was wide. His written contributions appeared in the principal library journals of this coun- 
try; in the Papers of the Bibliographical Society of America; American Notes and Queries, and the New York Times Book Review. $\mathrm{He}$ collaborated with $\mathrm{Paul}$ Saintonge in the compilation and publication in 1942 of Fifty Years of Molière Studies: a Bibliography, I892-194I, and was editor of Library Notes, a publication of the Friends of Duke University Library.

Christ's interest in music and the theater led him to become one of the charter members and founders of the Durham Choral Society and to active participation in the drama groups of the city. He was a regular member of the choir of the First Presbyterian Church.

He was a serious student of all aspects of library service, and his contribution to the Duke University Library went far beyond readers' services. He was an effective agent for the Library throughout the university and community and among its Friends around the world. Librarianship will miss his intelligent and creative interest in its problems, but his colleagues will miss him in a deeper fashion as a friend whose qualities of mind and heart were increasingly cherished through the years.-Benjamin E. Powell.

Lucy Lewis, Director of Libraries, Emeritus, for the Oregon State System of Higher Education, died in Corvallis, Oregon on December 5, 1951. Miss Lewis, a graduate of Pomona College and the University of Illinois Library School held her first important assignment as Librarian of New Mexico State College. After five years in this position she accepted, in $191 \mathrm{I}$, appointment as Assistant Librarian of Oregon State College. In 1920 she succeeded Mrs. Ida Kidder as Librarian of the State College.

At the time of the unification of all the state supported institutions of higher education in Oregon, in 1932, Miss Lewis was named Director of Libraries for the State System of
Higher Education; continuing to serve also as Librarian of the State College. In this difficult assignment she demonstrated exceptional administrative abilities. By steering a middle course between the extensive authority vested in her and the realities of the situation she was able to bring the libraries through the pioneer period of superimposed unification, by administrative edict, and to coordinate and integrate their work and activities more harmoniously than might have been expected. She left the libraries, at the time of her retirement, as one of the more successful phases of the unification of the Oregon institutions.

Miss Lewis was active in the work of the professional associations at all levels. She took a leading part in the activities of the Agricultural Libraries Section of the ALA. In 1936-37 she served as President of the Pacific Northwest Library Association and it was under her that the first steps were taken for the establishment of the Pacific Northwest Bibliographic Center. She was also active in the work of the Oregon Library Association and brought many contributions to the cultural life of Oregon State College. She was a member of the Daughters of the American Revolution, the Oregon Academy of Sciences, Kappa Delta sorority and Zonta.

Miss Lewis, always a quiet and modest worker, served ably and with distinction in a period that produced many outstanding library leaders. Her achievements and her contributions, sound and enduring, will constitute a lasting monument for her. $-W$. $H$. Carlson.

Mrs. Merle Boub, head of the Acquisitions Department at the University of Chicago since September 1936, died on November 27, 1951.

Eileen Duggan, since 1944 editor of the Booklist of the American Library Association, died in Chicago on January 12.

\section{Cooperative Committee on Library Building Plans}

The Cooperative Committee on Library Building Plans has turned over to the Association of College and Reference Libraries its stock of publications. The only one still in print is The Third Princeton Conference, a meeting ... held at the Firestone Library ... April 4, 1949. Copies sell for $\$ 2.50$. Orders should be sent to the Association of College and Reference Libraries at 50 East Huron Street, Chicago, and checks should be made out to the Association. All other Cooperative Committee reports may be obtained on microfilm from the Department of Photographic Reproduction, University of Chicago Libraries. 